\title{
Use of Game-Based Guidance to Increase Career Awareness of Street Children
}

\author{
Elia Firda Mufidah
}

\author{
Universitas PGRI Adi Buana Surabaya \\ eliafirda@unipasby.ac.id
}

Submitted: 2019-08-21, Revised: 2019-10-27, Accepted: 2019-11-07

\begin{abstract}
Street children are still a problem that needs to be moved. There are still many street children who drop out of school and do not understand what is related to the work taken. Game-based tutoring is in accordance with guiding principles and games so that children can be interested in joining this service. This research method uses pretest-posttest one group pre-experimental design. This study aims to find out how to use this program. This program aims to increase awareness. The Wilcoxon Career Awareness Test Results were obtained by Asymp. Sig $=0.043$. Asymp comparison. Sig $=0.043<\alpha=0.05$ then Ho is accepted and H1 is rejected. Associated with a significant priority on the career awareness scores of street children before the implementation of assistance based on street children's awareness planning. The results of this study are increased career awareness of street children.
\end{abstract}

Keywords: Career Awareness; Game Based Guidance; Street Child

\section{Introduction}

Childhood is a time when someone gets important experiences that are made for future life. Childhood starts from the age of six years to mature sexually. Careers as an integral part of individual development, career development has been carried out a compilation of individuals into childhood. This is in accordance with McDaniels \& Hummel (1984) there are 3 advances in child development before consciousness (before 11 years), evolution (11-17 years) and preparation (17 years and above). If agreed with elementary school students, the stage that elementary school students go through is preparation for awareness. Career awareness is very important at the beginning of career development. Career awareness is a state, readiness, willingness in which individuals start, understand and live the career to be achieved within a certain period of time (Verianto, Suranata, \& Dharsana, 2014). Career awareness must be the basis before starting the career of his choice (Perry \& VanZandt, 2006). Career awareness stages become things that need attention. As suggested by Arrington (2000) where career development can begin in elementary classes through mindfulness training that helps with basic planning for successful career planning.

Research on the implementation of guidance and counseling in primary schools has not been done much. Guidance and counseling in elementary schools have their own challenges in seeing elementary school students still in transition when they play the future of schools that have more responsibility to get started. One of the implementations of guidance and counseling in elementary schools that combines games with guidance and counseling is a study from Rika (2010), regarding the use of game-based guidance for the vigilance of VA class students of Islamic Primary Schools getting the results of welfare improvement from $34 \%$ to $70,5 \%$. Research results from. From these data obtained a picture of children's awareness can be improved with game-based guidance. Game-based guidance encourages the inclusion of what is to be achieved from the level of success following the game.

According to Arrington (2000), the strategies used to implement career awareness are: infusion curriculum: integration of curriculum components and inclusion in academic curriculum, understanding current career interests: family history, self defense, and finally life skills or personal development: cooperative learning, self-esteem, self-confidence, individual learning styles, etc. Game-based tutoring uses the basis of implementing guidance and counseling for participation using cooperative learning that invites students to be active 
in the counseling process. Arrington's opinion is also used by researchers in developing career awareness assessment instruments.

Guidance and counseling in primary schools use direct behavioral consultation, so researchers use guidance services. Guidance is a game based guide. Game-based tutoring provides new packaging for providing guidance so that you can easily receive what is requested. The game used is a snake and ladder game that has been played. Indicators that must be agreed by individuals to increase career awareness are included in each number that is passed by the snakes and ladders. Package the concept of game-based will make the delivery of the material that we have planned will be more interesting because the counselee is fully involved physically and psychologically. In addition, the game gives a different impression in the counselee's memory of the reception of the material presented.

Street children, tekyan, arek kere, homeless children are children who are excluded economically and socially into the streets and more of them are still required to learn and must successfully overcome problems on the streets (Yunnyanto, 2018). Seeing children who enter the street world, we need to be able to enjoy it for the sake of street children. This condition is in accordance with the results of research conducted by Wahono (Rika, 2010) about the increasing number of children from school that is related to raising awareness about the development carried out in the past by growing up children. Seeing this, career awareness is very important to be instilled for street children. When we see the reality of street children must be resolved for school and earn money, then special directions are needed so that their awareness can be maximized. Career awareness not only helps street children who understand career paths but can help them understand how the path from career success is. To help with their planning.

The condition of street children in Bungkul Park is still concerning. Can street children who live there after school are employed by their parents to sell quail eggs and drinks. This continued until the morning. In addition, in Bungkul Park, volunteers from SSC (Save Street Child Surabaya) have started coordinating them to want to learn. SSC Removes street children who have dropped out of school from school. There are no parents of street children in Bungkul Park who do not allow students to participate in learning with SSC. Seeing this, are the writers interested in utilizing those who use game techniques in group counseling to increase career awareness of street children?

\section{Methods}

This research is a pre-experimental study by designing a Pretest-Posttest Design Group, which aims to study the significance of the use of related directions to increase the vigilance of street children. The procedures in one group pretest-posttest design (1) Wear T1, i.e. pretest, to measure the average of career awareness skills before the subject is taught with a game-based guidance method (2) Wear a subject with $\mathrm{X}$, which is a game technique in group guidance, for the use of a certain time (3) Give T2, ie posttest, to measure the average support ability after testing experimental variable X (4) comparing the means of T1 and T2 using the Wilcoxon test using SPSS 16.00. Conceptual framework of game-based guidance to increase street children's awareness in Bungkul Garden: 


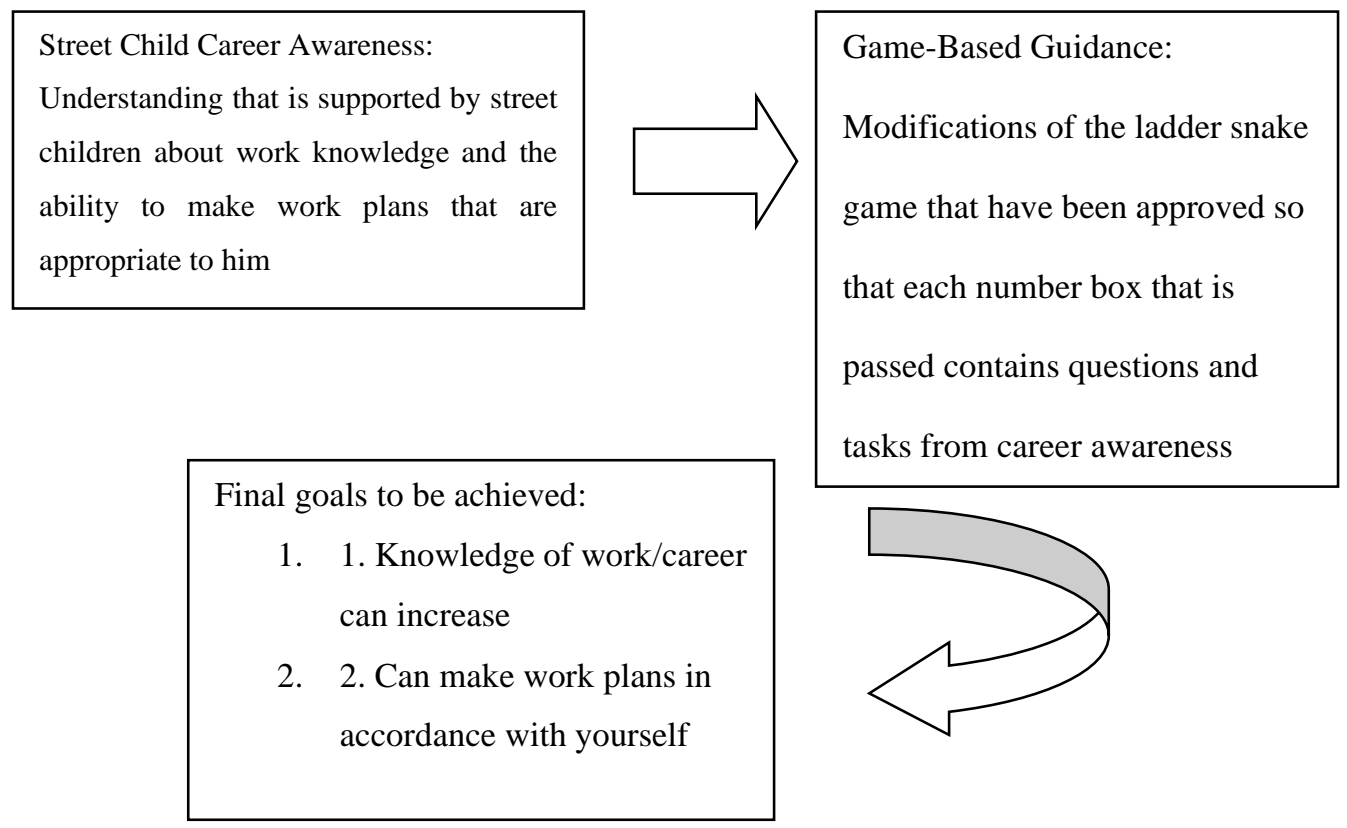

This study took the population of all street children in Bungkul Park. The number of street children in Taman Bungkul is 48 children (Data from SSC Surabaya). This amount contains street children who are members of the SSC from various levels of age. Starting from ummur 3-17 years.

The sample of this study was 5 street children taken by junior high school level taken by purposive sampling. Purposive sampling is used with the criteria of street children who are still running formal school. The author takes this technique as a sampling technique, depending on time, energy and funds, so the writer cannot take large and distant samples.

Data collection methods in this study are systematic and standard procedures to obtain the required data, both valid and reliable data. Data can be classified into two types namely, qualitative and quantitative data. Qualitative data is data that cannot be retrieved or stored in direct numbers. While quantitative data is data determined by a unit of numbers and represents a quantitative measure of objects arranged in a certain unit of measure.

In this study, the data obtained were qualitative and quantitative data. Qualitative data were obtained using the nontest technique, which is a data collection tool to find characteristics, with the results of the data containing definitions, consisting of questionnaires, interviews, and documentation. This study obtained qualitative data using interviews, observation and observation. While quantitative data were obtained using a measurement scale developed with a Likert scale. Career Awareness Measuring Instrument was developed by using 2 indicators, namely measuring career knowledge and career planning abilities.

The material used in this study was sourced from various media obtained through reference to various books and the internet. The tool used in this study is a game-based guidance media supported by Johari cards, cards and career awareness secret boards.

The scale of planning development awareness uses a Likert scale (Likert scale) with 4 answer choices, namely very understand (SF), understand (F), doubt (R), and not understand (TF), which was developed by researchers through the validity procedure content (content validity) and carried out a trial (try). Scale-up research uses scaling subjects. Positive claims give a score of 4 for strongly agree (SS), 3 for agree (S), 2 for doubt (R), 1 for not (T). While agreeing negatively gave a score of 1 for strongly agreeing (SS), 2 for agreeing (S), 3 for hesitation (R), and 4 for not (T). 
The procedure for developing this scale is as follows. First, research variables that are operational, namely career awareness variables. Second, developing the scale of blueprints, namely the scale of blueprint development. Third, managing development needs. Fourth, conduct an expert review (expert review) as a reference to revise the measurement scale. Fifth, try trials to try to find the validity of the evaluation scale of cooperation based on the balance of Cronbach's total Alpha thinking.

\section{Results and Discussion}

The sample that became counselee in this study was obtained from the results of purposive random sampling with the criteria of children entering or entering a new junior high school that was active on the streets after returning from school ages 13-14 in Bungkul Garden which produced 5 children. After the data is obtained, several suggestions come from each counselee. One counselee gets low score criteria and 4 counselees have medium criteria.

Table 1. Comparison Results of Pre-test and Post-test

\begin{tabular}{clccccc}
\hline No & Name & $\begin{array}{c}\text { Amount } \\
\text { (Pre test) }\end{array}$ & Category & $\begin{array}{c}\text { Amount } \\
\text { (Post test) }\end{array}$ & Category & $\begin{array}{c}\text { Difference } \\
\text { in Score }\end{array}$ \\
\hline $\mathbf{1}$ & Ary & 30 & Low & 45 & Sedang & 15 \\
$\mathbf{2}$ & Hr & 31 & Low & 46 & Sedang & 15 \\
$\mathbf{3}$ & Dk & 46 & Moderate & 60 & High & 14 \\
$\mathbf{4}$ & Rs & 48 & Moderate & 62 & High & 14 \\
$\mathbf{5}$ & Ul & 43 & Moderate & 53 & High & 10 \\
\hline
\end{tabular}

Based on the table above, it shows an improvement in results after being given a game-based treatment. The following activities during the process.

Table 2. Game-Based Guidance Process

\begin{tabular}{|c|c|c|}
\hline $\begin{array}{c}\text { Days } \\
\text { to }\end{array}$ & Activity & Results \\
\hline 1 & $\begin{array}{l}\text { Relationship recognition, consisting } \\
\text { of: } \\
\text { Introduction } \\
\text { Share about daily activities } \\
\text { Contract to follow game-based } \\
\text { guidance } \\
\text { Determination of the schedule of } \\
\text { game-based guidance activities }\end{array}$ & $\begin{array}{l}\text { Obtained the following results: } \\
\text { Knowing the identity of each } \\
\text { individual from the identity sheet } \\
\text { that has been distributed. } \\
\text { There is a closeness between } \\
\text { sharing a cell phone number } \\
\text { Determination of the schedule is } \\
\text { immediately carried out the next } \\
\text { day }\end{array}$ \\
\hline 2 & $\begin{array}{l}\text { Activity } 1 \\
\text { Distribution window of Johari sheet } \\
\text { Implementation of the first game } \\
\text { (Self-understanding) } \\
\text { Evaluate the game } 1\end{array}$ & $\begin{array}{l}\text { Results obtained from activity } 1 \text { : } \\
\text { Self-understanding of the game } 1 \\
\text { The counselee knows what is } \\
\text { missing from the question in game } \\
1\end{array}$ \\
\hline 3 & $\begin{array}{l}\text { Activity 2: } \\
\text { Distribution of results from the Johari } \\
\text { window sheet } \\
\text { Game implementation } 2 \\
\text { Game evaluation } 2\end{array}$ & $\begin{array}{l}\text { The results obtained: } \\
\text { The counselee knows his } \\
\text { personality type from the Johari } \\
\text { window analysis which is } \\
\text { consistent with Holland's theory } \\
\text { Career understanding and general } \\
\text { career requirements } \\
\text { The counselee knows what is }\end{array}$ \\
\hline
\end{tabular}




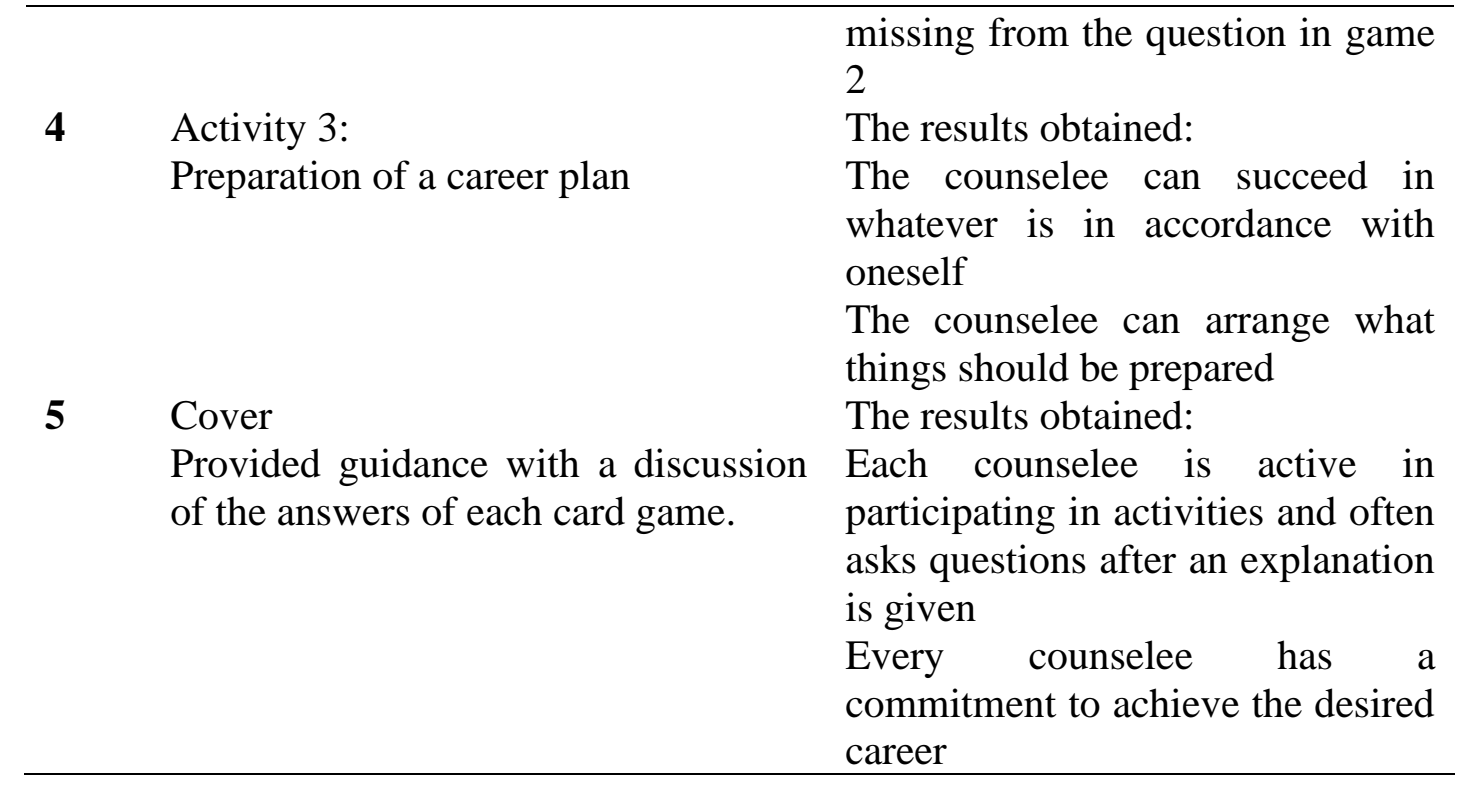

An increase occurred in each individual. This difference is caused by various backgrounds issued by the counselee. This background can be caused by family problems or pre-existing problems. Of course, things in each counselee are not the same. This is described as follows.

a. Responden Ary

Counselee pre-test results get a value of 30 with a low category. After treatment, the counselee gets added value to 45 in the medium category, that is, before conducting counseling care about understanding themselves and after being given guidance counselees can understand anyone and analyze their talents and interests.

b. Responden $\mathrm{Hr}$

The counselee pre-test results obtained a total of 31 in the low category. After being given the treatment, it is gained to an increase of 46 in the medium category. The increase that occurred in terms of understanding himself, who was initially confused by who he was after being given counselee counsel can explain the meaning expressed and analyze how to associate it with reference to the window given Johari.

c. Responden Dk

The counselee pre-test results obtained a total of 46 in the medium category to 60 in the high category. Improvement in preparation for career planning, which initially could not save better with the interests of saving. In addition, the counselee who was initially still confused by wanting to change the direction in which his career can be approved in accordance with his condition.

d. Responden Rs

The counselee pre-test results obtained a total of 48 in the medium category to 62 in the high category. The changes that occur are counselees who may be better among their ideals who were still confused with their ideals.

e. Responden U1

The results of pre-test counselees who get a total of 43 values in the medium category became 53 with a high category. The change that occurs is an understanding of the school environment. The counselee whose origins are still unable to solve any part that has been processed into the understanding of important places in his school.

Based on the calculation results obtained Asymp. Sig $=0.043$. Asymp comparison. Sig $=0.043<\alpha=0.05$ then Ho is accepted and H1 is rejected. Associated with a significant 
priority to the career awareness scores of street children before the implementation of game assistance in group guidance to the career awareness of street children in Bungkul park.

Guidance is one aspect of Guidance and Counseling. Between guidance and counseling are 2 things that are interconnected. Guidance is a translation of the word guide, which comes from the word guide, has the meaning indicated, guided, directed, directed, supported, given. Basically guidance has diversity in its understanding. Guidance means having a different meaning from counseling.

According to (Fitriani, 2016), guidance is an ongoing process of assistance carried out by mentors, which is prepared for each individual who needs it in order to develop the potential that is facilitated by using various kinds of media and guidance techniques in a normative care context so that individuals can benefit both himself or his environment. According to (Amin, 2013), guidance is assistance given to others so that the community can develop their potentials in an effort to overcome various problems, so they can determine their own way of life that is responsible for staying accessible to others, and that assistance has done continuously.

Career awareness is the foundation to be developed. Three aspects of career development are 1) Competency needs and self-awareness of career potential, indicators: (a) Self-awareness, (b) Educational awareness, (c) Career awareness, ( d) Economic awareness. 2) Competence of challenging perceptions about the world of work, indicators: (a) Decision making (b), (b) Initial competencies. 3) Competence can connect with the world of work, indicators: (a) Work skills, (b) Attitudes and appreciation (Hidayati, 2015). T.Eliason (2008) declare career awareness of individual awareness about available career opportunities and their career needs. Awareness includes information about educational requirements, skills requirements, types of professions available, job difficulties, and regulations and expectations of certain fields or industries. Anderson (2012) describes the awareness of participation at the individual level and the knowledge of what they have to do to enter and progress at the bidder career.

Games are fun activities carried out by everyone. Free game between not psychic and physical individual. Besides being able to make psychic or mood can be fun, physical can be better to be moved. According to Freud and Erickson (Santrock, 2006) the game is a human work that is very useful, helping children who are trained and conflict. Because pressures are released in the game, children can overcome life's problems. Games can also help children with their social environment (Wardhani, 2016).

Abidin, Osman, \& Hosseini (2012) results from his research is a game that has been proven to be a significant factor in improving self-concept. The concept of self becomes the basis for fulfilling an individual's career understanding. Career awareness provided in this guidance-based starts from self-understanding, understanding the environment and decision making as part of career planning. The given game starts with a finish done by yourself. This is very important in career awareness. Guidance will end with the guidance they decide.

Arrington (2000), the strategies used to achieve career goals are infusion curriculum, current career approval, and life skills or personal development. Game-based counseling services provide fun for the counselee. Counselors for the game and complete the tasks provided in the game media provided by the counselor. Street children who are not easy to interact with our catharsis through games that are used by counselors in providing guidance services. Counselees are not fixated and not too nuanced formalities following this program.

The results of the post-test that have been given to 5 counselees only need to be Increased in Success in the medium category of 2 counselees and high 3 counselees. This is due to several registrant factors:

1. Each counselee has a different personality according to the Dutch theory obtained from the Johari window analysis. 

a. Ary's counselee is an investigative personality type
b. Hr counselee are artistic personality types
c. Counselee Dk type social personality
d. Rs counselee are of social personality type
e. Ul's counselee is of the conventional personality type

2. When doing guidance based on the game is still not running optimally because when giving full guidance by people who are passing by so that the counselee is less successful to do guidance

3. Different from different family backgrounds with different career awareness

4. Researchers are prospective counselors who are still lacking in providing assistance to counselees

5. Short time for assistance with guidance because the counselee must complete the task of making money.

\section{Conclusions and Suggestions}

Based on the results of this study, the authors conclude that there is a significant influence on the use of game techniques in group guidance to increase career awareness of street children. This is evidenced by the criteria for increasing counselees whose origins are low to medium and those that are initially high Although not all counselees get high criteria, there has been an increase in all consumers. This disparity is due to differences in the background of each counselee.

Based on the results of research conducted, with proven evidence related to positive use in training in Bungkul Park, it can be given to institutions that are involved in dealing with street children who contain to raise awareness of children on the street that can be given game techniques in group guidance so The counselee can be more interested in reaching the level of career awareness, because with the media the game counselee can be more enthusiastic to want to take guidance. This research can be used for further research.

\section{References}

Abidin, M. J. Z., Osman, S. R. F., \& Hosseini, M. S. (2012). Role-play: taking the line of least resistance. International Journal of Learning \& Development, 2(2), 258-270.

Amin, S. M. (2013). Bimbingan dan Konseling Islami. Jakarta: Amzah.

Anderson, L. (2012). Career Awareness: Second Careers, Career Reentry. Virginia: ICF International.

Arrington, K. (2000). Planning Programs. The American Journal of Nursing, 31(2), 186. https://doi.org/10.2307/3411121

Fitriani, M. (2016). Problem Psikospiritual Lansia Dan Solusinya Dengan Bimbingan Penyuluhan Islam ( Studi Kasus Balai Pelayanan Sosial Cepiring Kendal ) Mei Fitriani Penyuluh Agama Tetap Non PNS Kabupaten Pemalang. 70-95.

Hidayati, R. (2015). Layanan Informasi karir membantu peserta didik dalam meningkatkan pemahaman karir. Jurnal Konseling GUSJIGANG, 1(1).

McDaniels, C., \& Hummel, D. (1984). Parents and career education. Journal of Career Education, 10(4), 225-233.

Perry, N., \& VanZandt, Z. (2006). Exploring future options: A career development curriculum for middle school students. IDEA.

Rika. (2010). Penggunaan Media Permainan Untuk Mengembangkan Kesadaran Karir Anak Studi Pengembangan Program Pada Kelas Atas Sekolah Dasar Islam Terpadu- 
Sumedang. Tahun Pelajaran 2009-2010. (Universitas Pendidikan Indonesia). Retrieved from http://repository.upi.edu/8922/

Santrock, J. (2006). Life - Span development : perkembangan masa hidup. Jakarta: Erlangga.

T.Eliason, G. (2008). Career Development in the Schools. United States: Information SAGE Publishing.

Verianto, A., Suranata, K., \& Dharsana, I. K. (2014). Penerapan Model Perkembangan Karir Ginzberg dengan Menggunakan Teknik Modeling untuk Meningkatkan Kesadaran Karir pada Siswa Kelas X TKR3 SMK Negeri 3 Singaraja. Jurnal Ilmiah Bimbingan Konseling Undiksha, 2(1).

Wardhani, J. D. (2016). Peran Permainan Musik Feeling Band Terhadap Perkembangan Emosi Anak.

Yunnyanto, E. E. (2018). Pelayanan Sosial Anak Jalanan Melalui Pendidikan Keterampilan Di Yayasan Nara Kreatif Jakarta Timur. Fakultas Ilmu dakwah dan Ilmu Komunikasi Universitas Islam Negeri Syarif Hidayatullah Jakarta. 